\title{
ブリーディング現象と塗料の新たな動的保水性測定の試み
}

\author{
日本ゼオン株式会社 小林 賢，奥山 剛，小池敏夫
}

\section{Bleeding Phenomena and a new Trial of Measurement of Dynamic Water Retention on Coating Color}

\author{
Takashi Kobayashi, Tuyosi Okuyama and Toshio Koike \\ Nippon Zeon Co., Ltd.
}

\begin{abstract}
We investigated to relation between bleeding and fluidity, dynamic water retention in order to search appearance factor of bleeding phenomena. Dynamic water retention mesured by moisture meter.
\end{abstract}

Conclusions :

(1) We found out significant correlation between bleeding and fluidity, dynamic water retention by result of test coater.

(2) Moisture meter is possible to measurement of dynamic water retention.

(3) IGT printability tester is possible to measurement of dynamic water retention (laboratory scale).

\section{1. 緒言}

近年，塗工紙を製造するにあたって品質・生産性共 に優れているという点からブレードコーターによる塗 工が多くなってきている。ブレードコーターの塗工速 度は従来では $1,000 \mathrm{~m} / \mathrm{min}$. 前後が一般的であったが, 生産性向上の観点から $1,500 \mathrm{~m} / \mathrm{min}$. 以上の高速塗工 が種々のコーターで試みられている。高速塗工の際に 生じる問題点にはストリーク・スクラッチの発生，摩 耗によるブレードの頻繁な取替え等の他にブリーディ ング (刃もれ) という現象がある。これはブレードの 出口後方に塗料が堆積する現象であり，少量のドライ なブリーディングであれば後方に落下するので生産・ 品質には影響しない。しかしウェットなブリーディン グは塗工紙上に接着し表面の不均一性を引き起こし， 最終製品の品質に影響を及ぼすこともある。

このブリーディングの関しては, 塗料の流動性・保 水性の影響が大きいと考えられているが, 実際の操業 との関係を知る上では従来の静的保水性だけでは十分 と言えず，動的保水性に関する知見が必要である。こ の動的保水性を測定する手段は動的浸透性試験機によ る方法, 或いは塗工直後の塗料を削り取ってその濃度
を測定する方法等検討がなされている。実際にはパイ ロットコーターや実機での検討法である後者が主流で あるが,

・削り取る塗工層の厚さが不正確

・削り取りから測定までの間に塗料の乾燥が進行し, 高めの值となり不正確

・製造工程上での測定には無理がある

等の問題点がありリアルタイムで測定しにくい。

本報ではこの動的保水性の測定手段として，水分子 が近赤外線中の特定波長の光を吸収することに着目し， 塗工直後の水分率をリアルタイムに測定することを検 討した。また実験室規模での動的保水性の測定法とし て, IGT 印刷適性試験機を使用して流動性・動的保 水性の評価を検討した。更に, この方法で得られたデ 一タに基づき，ブリーディングと動的保水性の関係を 検討した。

\section{2. 実験方法}

\section{1 塗料配 合}

塗料配合は表 1 に示すように焼成クレーを含む塗料 I と焼成クレーを含まない塗料IIにより行なった。塗 料の作成にはコーレスミキサー分散機を使用した。 
表 1 配合表

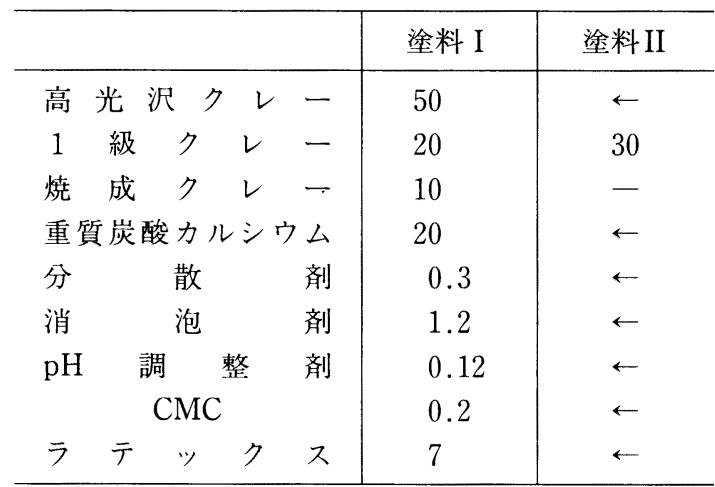

塗料固形分濃度： $65 \%$

\section{2 ラテックス}

ラテックスは表 2 に示す 3 種を使用した。ラテック ス $\mathrm{B}$ はラテックス $\mathrm{A} の$ 塗料流動性改良を目的とした ものであり，ラテックス $\mathrm{C}$ はラテックス $\mathrm{B}$ の保水性 改良を目的としたものである。

\section{3 水分率計}

水分率計は東京試験機製作所秼製 JE-100 使用し た。予備実験として手動ブレード塗工機を用いて水の 吸収波長帯での反射率と塗料固形分濃度の関係を求め, 測定の可能性を検討した。

\section{4 テストコーター}

テストコーターは石川島播磨重工業侏製のバリドウ エルジェット型ファウンテン式ブレードコーターを使 用した。テスト条件を以下に示す。

・原紙：上質紙/中質紙

・塗料濃度：約 $62 \sim 65 \%$ (塗工毎に塗工直前にサ ンプリングし濃度を確認した)

・塗工速度：500 1,500 $\mathrm{m} / \mathrm{min}$.

・ブレード条件：厚み $0.5 \mathrm{~mm}$, ブレード角 35 度

・ブレード圧：0.5 1.5 kg/cm

・目標塗工量 : 8 $10 \mathrm{~g} / \mathrm{m}^{2}$

・水分率計設置位置：ブレード中央部・ブレード刃 先から上方 $20 \mathrm{~cm}$ の位置

\subsection{IGT 印刷適性試験機による流動性・動的 保水性の検討}

IGT 印刷適性試験機を使用して塗料の流動性・動 的保水性の測定可否を検討した。

\section{試験 方法}

(1) IGT 印刷適性試験機のセクターにPET フィル ムをセットし, 塗料を注射器を用いて一定容 量・一定面積となるようにセクターと印刷ディ スクの接合部に塗布する。

（2）試験器を作動し, 塗料を PET フィルム上に伸 展させる。

（3）次に上質紙をセットして同様の操作を行なう。

(4) 次の数値を算出する。

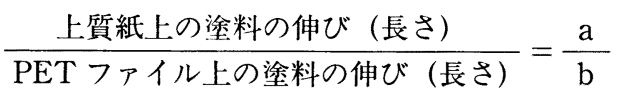

\section{3. 結果と考察}

\section{1 水分率計による動的保水性測定の可能性 テスト}

今回使用予定の水分率計の実際の塗工の場での測定 可能性を検討した。テストは熊谷理機製卓上手動ブレ ードコーターを使用して行なった。

\section{テスト条件}

- 塗料：塗料 $\mathrm{I}$, ラテックス $\mathrm{A}$, 塗料固形分濃度 $63 \sim 67 \%$

- 原紙：上質紙

・水分率計設置位置：ブレード中央部・ブレード刃 先から後方 $30 \mathrm{~cm}$ の位置

結果を図 1 に示す。塗料固形分濃度の低下に伴い反 射率の低下，即ち塗工層中の水分が上昇していること がわかる。また塗工量には無関係と考える。

以上より, 塗工直後の塗工層の水分率をリアルタイ ムで測定可能と考える。

\section{2 テストコーターによる塗エテスト}

(1) ブリーディングと各因子との関係

テストコーターにおいてブリーディング発生に関与 する因子を検討した。

表 2 ラテックス

\begin{tabular}{c|l|c|c|c}
\hline ラテックス & 内容 & 粒径 $(\AA)$ & ゲル $(\%)$ & $\mathrm{Tg}\left({ }^{\circ} \mathrm{C}\right)$ \\
\hline $\mathrm{A}$ & $\mathrm{SB}$ ラテックス & 930 & 77 & -3 \\
$\mathrm{~B}$ & $\mathrm{SB}$ ラテックス & 840 & 82 & -4 \\
$\mathrm{C}$ & ラテックスBに保水性を付与 & 840 & 82 & -4 \\
\hline
\end{tabular}




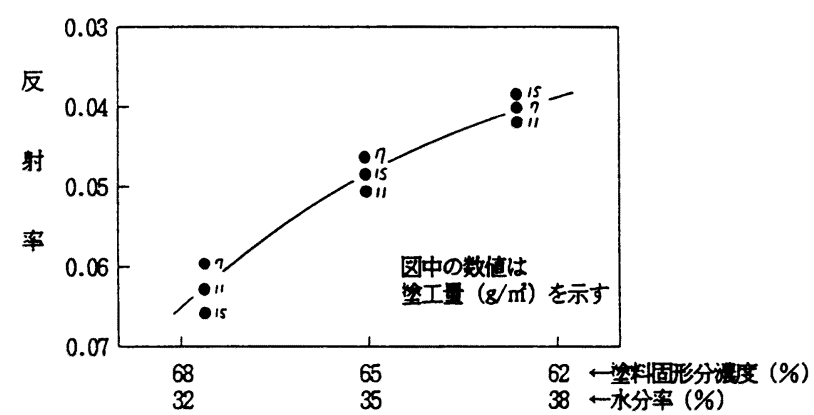

図 1 水分率と反射率の関係

表 3 塗工条件とブリーディング発生速度の関係(1)

\begin{tabular}{|c|c|c|c|c|c|c|c|c|c|c|c|c|}
\hline \multirow{2}{*}{$\begin{array}{c}\bar{\tau} \\
\text { ス } \\
\text { 卜 } \\
\text { No. }\end{array}$} & $\begin{array}{c}\text { 条件：ラテックス } \\
\text { 上質紙 } \\
\text { 塗料固形分濃度 } \quad 64.5 \%\end{array}$ & \multicolumn{11}{|c|}{ 塗工速度 $(\mathrm{m} / \mathrm{min}$.$) とブリーディング（ウェット）発生状況*$} \\
\hline & 料 & 500 & 600 & 700 & 800 & 900 & 1,000 & 1,100 & 1,200 & 1,300 & 1,400 & 1,500 \\
\hline 1 & 塗料 I （焼成クレ一有） & $\bigcirc$ & $\bigcirc$ & $\bigcirc$ & $\bigcirc$ & $\triangle$ & $x$ & $x$ & $x$ & $x$ & $x$ & $x$ \\
\hline 2 & 塗料 II（焼成クレ一無） & $\bigcirc$ & $\bigcirc$ & $\bigcirc$ & $\bigcirc$ & $\bigcirc$ & $\bigcirc$ & $\bigcirc$ & $\bigcirc$ & $\triangle$ & $x$ & $x$ \\
\hline
\end{tabular}

* $\bigcirc$ : 発生せず $\triangle$ : 発生（微量） $\times$ : 発生（玉状）

表 4 塗工条件とブリーディング発生速度の関係(2)

\begin{tabular}{|c|c|c|c|c|c|c|c|c|c|c|c|c|c|}
\hline \multirow{2}{*}{$\begin{array}{l}\text { テ } \\
\text { ス } \\
\text { ト } \\
\text { No. }\end{array}$} & \multicolumn{2}{|c|}{$\begin{array}{r}\text { 条件：塗料 I } \\
\text { 上質紙 }\end{array}$} & \multicolumn{4}{|c|}{ 塗工速度 $(\mathrm{m} / \mathrm{min})}$. & \multicolumn{6}{|c|}{ とブリーディング（ウェット）発生状況 } & \multirow[b]{2}{*}{1,500} \\
\hline & $\begin{array}{l}\text { ラテック } \\
\text { ス }\end{array}$ & $\begin{array}{c}\text { 塗料固形分濃度 } \\
(\%)\end{array}$ & 500 & 600 & 700 & 800 & 900 & 1,000 & 1,100 & 1,200 & 1,300 & 1,400 & \\
\hline 1 & A & 64.5 & $\bigcirc$ & $\bigcirc$ & $\bigcirc$ & $\bigcirc$ & $\triangle$ & $x$ & $x$ & $x$ & $x$ & $x$ & $x$ \\
\hline 3 & $\mathrm{~B}$ & 64.5 & $\bigcirc$ & $\bigcirc$ & $\bigcirc$ & $\bigcirc$ & $\triangle$ & $\times$ & $\times$ & $x$ & $x$ & $\times$ & $x$ \\
\hline 4 & $\mathrm{C}$ & 64.5 & 0 & 0 & 0 & 0 & 0 & 0 & 0 & 0 & $\triangle$ & $\times$ & $x$ \\
\hline
\end{tabular}

表 5 塗工条件とブリーディング発生速度の関係(3)

\begin{tabular}{|c|c|c|c|c|c|c|c|c|c|c|c|c|}
\hline \multirow{2}{*}{$\begin{array}{c}\text { テ } \\
\text { ス } \\
\text { ト } \\
\text { No. }\end{array}$} & $\begin{aligned} \text { 条件：塗料 I } & \\
& \text { ラテックス } \mathrm{B}\end{aligned}$ & \multicolumn{4}{|c|}{ 塗工速度 $(\mathrm{m} / \mathrm{min})}$. & \multicolumn{6}{|c|}{ とブリーディング（ウェット）発生状況 } & \\
\hline & 塗料固形分濃度（\%) & 500 & 600 & 700 & 800 & 900 & 1,000 & 1,100 & 1,200 & 1,300 & 1,400 & 1,500 \\
\hline 3 & 64.5 & $\bigcirc$ & O & $\bigcirc$ & $\mathrm{O}$ & $\triangle$ & $x$ & $x$ & $x$ & $x$ & $x$ & $\times$ \\
\hline 5 & 62.5 & $\bigcirc$ & $\bigcirc$ & 0 & O & O & $\bigcirc$ & $\bigcirc$ & O & $\triangle$ & $\triangle$ & $\triangle$ \\
\hline
\end{tabular}

\section{検討した因子}

(1)焼成クレーの有無（表 3)

(2)ラテックスの相違（表 4)

(3)塗料固形分濃度の影響（表 5)
(4) CMC 添加量（表 6)

(5)原紙の相違（上質紙・中質紙）（表 7)

(2) ブリーディングと反射率の関係

ブリーディングの発生状況把握と並行して水分反射 
表 6 塗工条件とブリーディング発生速度の関係(4)

\begin{tabular}{|c|c|c|c|c|c|c|c|c|c|c|c|c|c|}
\hline \multirow{2}{*}{$\begin{array}{c}\text { テ } \\
\text { ス } \\
\text { ト } \\
\text { No. }\end{array}$} & \multicolumn{2}{|c|}{$\begin{array}{l}\text { 条件：塗料 I } \\
\text { ラテックス } \mathrm{C} ・ \text { 上質紙 }\end{array}$} & \multicolumn{4}{|c|}{ 塗工速度 $(\mathrm{m} / \mathrm{min}$. } & \multicolumn{7}{|c|}{ とブリーディング（ウェット）発生状況 } \\
\hline & $\begin{array}{l}\text { CMC } \\
\text { (部) }\end{array}$ & $\begin{array}{c}\text { 塗料固形分濃度 } \\
(\%)\end{array}$ & 500 & 600 & 700 & 800 & 900 & 1,000 & 1,100 & 1,200 & 1,300 & 1,400 & 1,500 \\
\hline 4 & 0.2 & 0 & $\bigcirc$ & $\bigcirc$ & $\bigcirc$ & O & 0 & $\triangle$ & $x$ & $x$ & $x$ & $x$ & \\
\hline 6 & 0.5 & 0 & $\triangle$ & $x$ & $\times$ & $\times$ & $x$ & $x$ & $x$ & $x$ & $x$ & $x$ & \\
\hline
\end{tabular}

表 7 塗工条件とブリーディング発生速度の関係(5)

\begin{tabular}{|c|c|c|c|c|c|c|c|c|c|c|c|c|c|c|}
\hline \multirow{2}{*}{$\begin{array}{l}\text { テ } \\
\text { ス } \\
\text { ト } \\
\text { No. }\end{array}$} & \multicolumn{3}{|c|}{$\begin{array}{l}\text { 条件：塗料 I } \\
\text { ラテックス } \mathrm{C} \\
\text { 塗料固形分濃度 } \quad 64.5 \%\end{array}$} & \multicolumn{4}{|c|}{ 塗工速度 $(\mathrm{m} / \mathrm{min})}$. & \multicolumn{6}{|c|}{ とブリーディング（ウェット）発生状況 } & \multirow[b]{2}{*}{1,500} \\
\hline & 原 & & 紙 & 500 & 600 & 700 & 800 & 900 & 1,000 & 1,100 & 1,200 & 1,300 & 1,400 & \\
\hline 4 & 上 & 質 & 紙 & O & $\bigcirc$ & O & O & $\bigcirc$ & O & $\triangle$ & $\times$ & $\times$ & $\times$ & $x$ \\
\hline 7 & 中 & 質 & 紙 & $\bigcirc$ & $\bigcirc$ & $\bigcirc$ & $\bigcirc$ & $\bigcirc$ & $\triangle$ & $\times$ &.$x$ & $\times$ & $x$ & $x$ \\
\hline
\end{tabular}

表 8 塗料ハイシア流動性

\begin{tabular}{c|c|c}
\hline ラテックス & $\begin{array}{c}\text { 塗料固形分 } \\
\text { 濃度 }(\%)\end{array}$ & $\begin{array}{c}\text { ハイシア粘度 } \\
\text { ( } \mathrm{G} \text { ボブ使用・6,600 } \\
\mathrm{rpm} .)\end{array}$ \\
\hline $\mathrm{A}$ & 64.5 & 42.3 \\
$\mathrm{~B}$ & 64.5 & 40.5 \\
$\mathrm{~B}$ & 62.5 & 33.3 \\
$\mathrm{C}$ & 64.5 & 41.2 \\
$\mathrm{C}(\mathrm{CMC} 0.5$ 部 $)$ & 62.5 & 44.5 \\
\hline
\end{tabular}

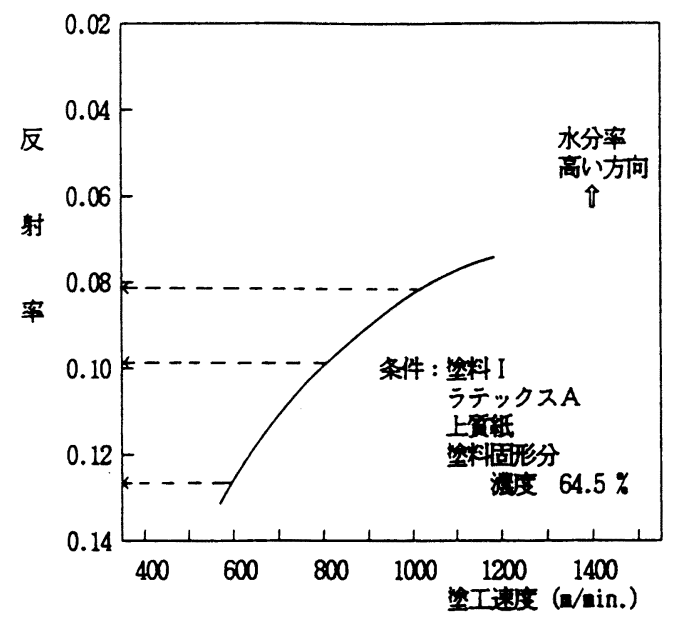

図 2 塗工速度と反射率の関係(1)
率の測定も行なった。前記(2)項を例にとって説明する。 実際の測定で得られたデー夕はそれぞれ図2～図 7 の ようになった。

図 2 図 7 各々のデータから図中に矢印で示したよ うに $600,800,1,000 \mathrm{~m} / \mathrm{min}$.の塗工速度における 反射率を読み取る。この反射率と塗料固形分濃度 (水

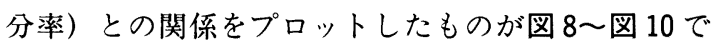
ある。

尚，図2＼cjkstart図 10 において水分率が高い方向をグラ フの上方向表示とするために反射率の数值を逆転（上 方向ほど反射率が小さい)させた。

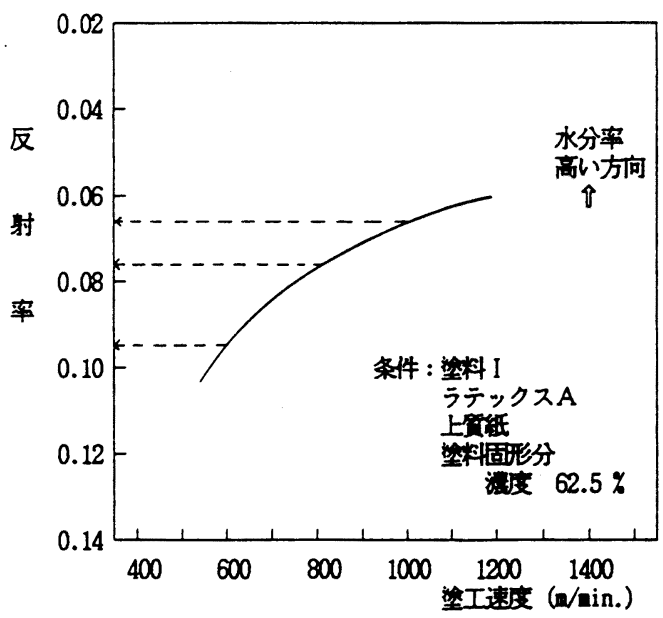

図 3 塗工速度と反射率の関係(2) 


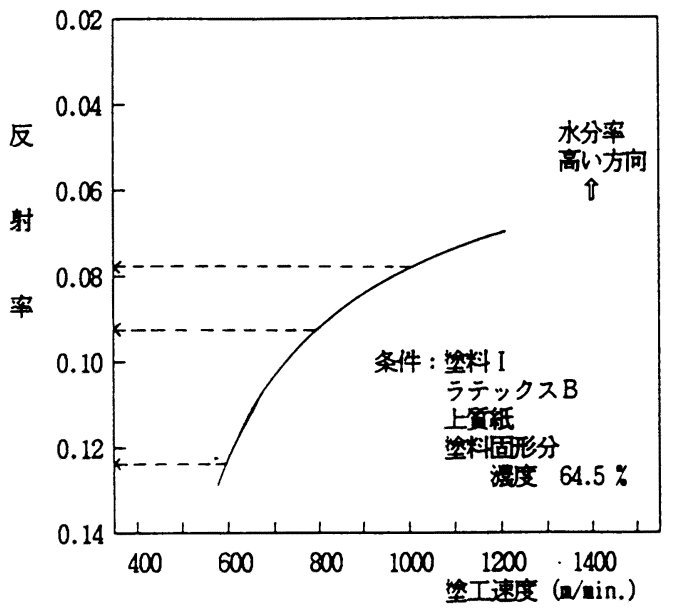

図 4 塗工速度と反射率の関係(3)

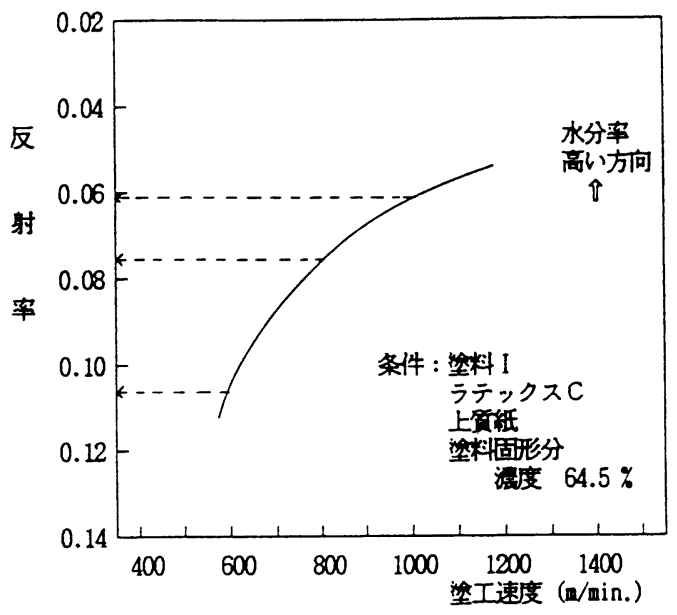

図 6 塗工速度と反射率の関係(5)

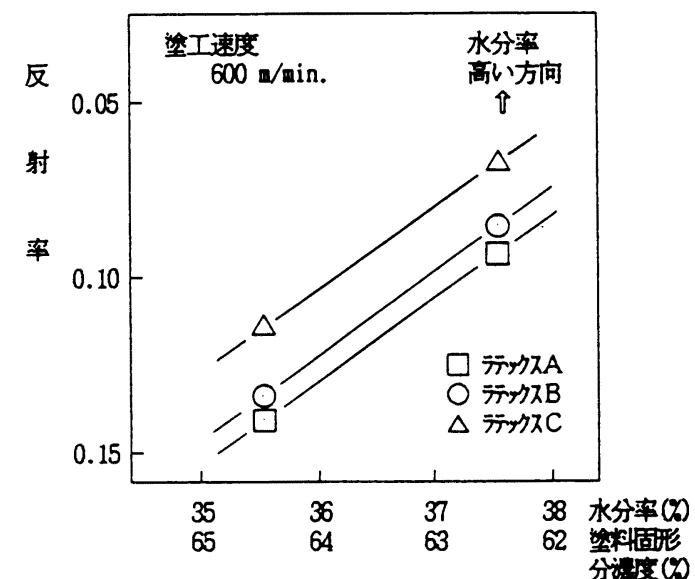

図 8 同一塗工速度における塗料固形分濃度と反射 率の関倸(1)

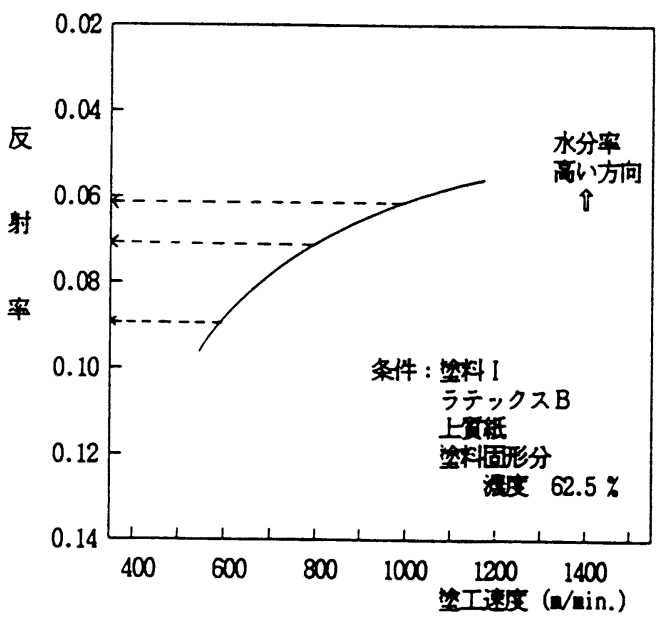

図 5 塗工速度と反射率の関係(4)

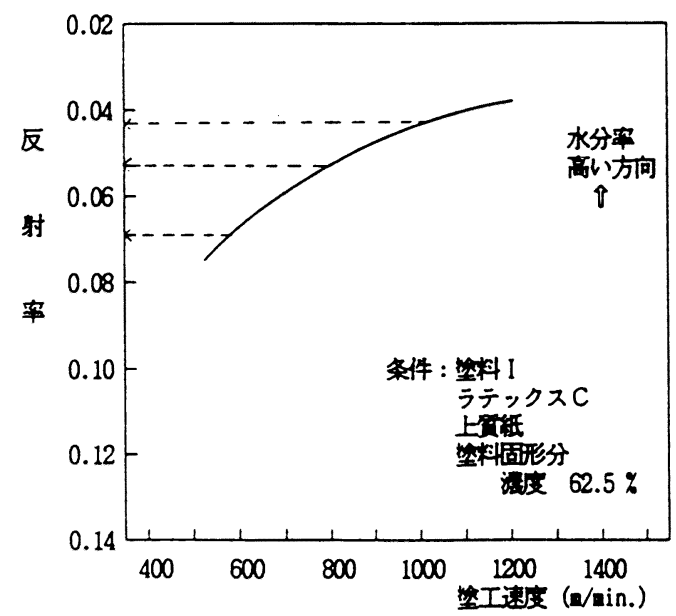

図 7 塗工速度と反射率の関係(6)

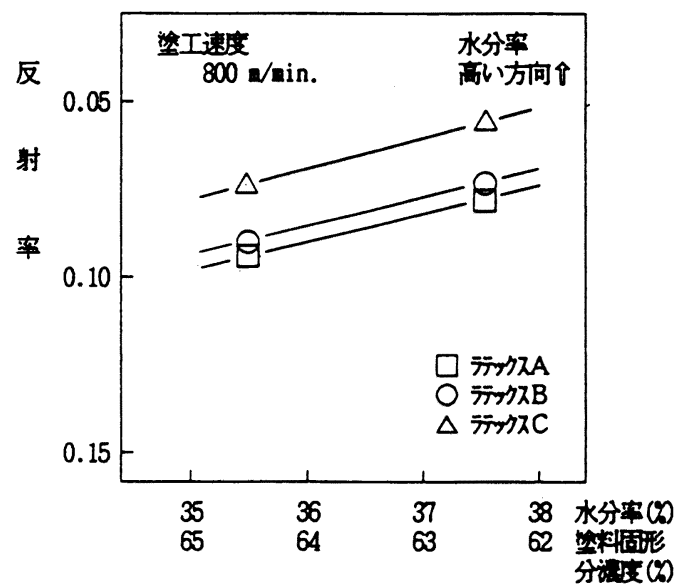

図 9 同一塗工速度における塗料固形分濃度と反射 率の関倸(2) 


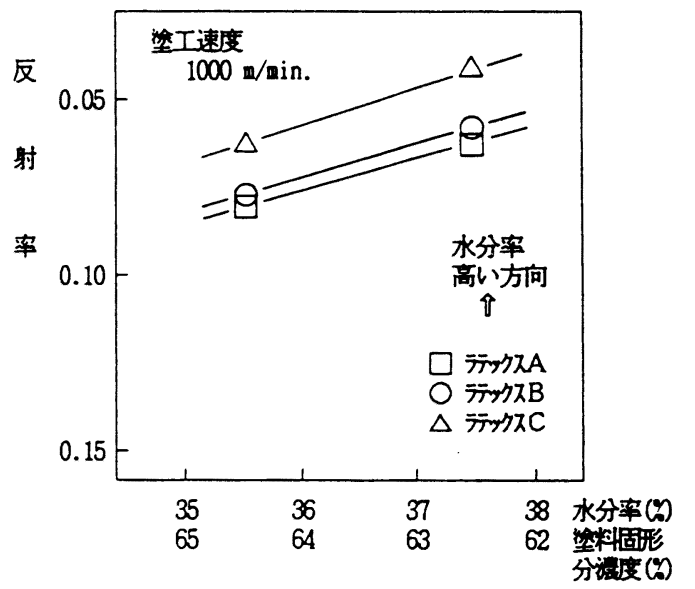

図 10 同一塗工速度における塗料固形分濃度と反射 率の関係(3)

(3) 考察

一般に焼成クレー含有配合ではブリーディングが発 生し易い傾向にあることが知られているが，表 3 に示 すように本実験においても同様な結果となった。

表 8 に各塗料のハイシア流動性の結果を示す。表 4 よりラテックス A の流動性を改良したラテックス $\mathrm{B}$ でもブリーディングの発生速度は同等であり，改良に 到っていない。しかし更に塗料固形分濃度を下げると ブリーディングは良好な結果となった（表 5)。塗料 のハイシア流動性を大幅に向上させれば良好になると 考えられる。

一方ラテックス B に保水性を付与したラテックス Cではラテックス $\mathrm{A}$ と同等の流動性を示しているが, ラテックス $\mathrm{A} よ り も$ 高速域に到るまでブリーディン グが発生しない。ラテックスの保水性改良によりブリ ーディングは改良できると考えられる。

このことは水分反射率の測定結果からも説明できる。 四 8〜図 10 より，ラテックス $\mathrm{C}$ の同一塗工速度にお

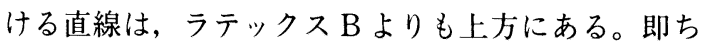

同一塗工速度では水分率は常にラテックス $\mathrm{C}$ のほう が高い。これはラテックス Cのほうが塗工直後の塗 工層の水分率が高く，従って動的保水性が良好である 事を示している。ブリーディングはラテックス Cの ほうが良好であり, 結局塗料のハイシア流動性が良く, 動的保水性が良いほうがブリーディングが抑えられる と考えられる。またラテックス $\mathrm{A}$ とラテックス Bで はほぼ同一線上となっているが, これは動的保水性の 差は殆んどないためと考えられる。以上のように各塗 工速度における反射率と水分率（塗料固形分濃度）の 関係により同一条件において塗工した塗料については 反射率よりブリーディング発生の傾向がつかめそうで ある。

しかし表 6 に示すように, CMC 増量して更に保 水性をアップしたものに関しては塗料固形分濃度が低 下しているにも関わらずブリーディングには悪影響を 及ぼす結果となった。これは流動性低下の影響が大き いと考えられる。CMCのような水溶性高分子を添加 した場合には保水性はアップするが流動性は低下する。 それに対してラテックス C は保水性改良効果がある にも関わらず流動性は低下しない。従って流動性・保 水性の両面を考え合わせると，ラテックスでの改良の ほうが有利と考えられる。

また表 7 よ原紙による差に関しては上質紙よりも 中質紙のほうがブリーディングには悪影響を与える。 これは上質紙よりも中質紙のほうが水を吸い易く，塗 料中の水分が原紙に移動してより固形分濃度が上昇す るためと考えられる。

\subsection{IGT 印刷適性試験機による流動性・動的 保水性測定の可否検討}

テストコーターにおいては動的保水性に優れた塗料 ほどブリーディングは良好な結果であったが，これを 確認する意味で IGT 印刷適性試験機によるテストを 行ない, 塗料の流動性・動的保水性の測定可否を検討 した。

表 9 IGT 印刷適性試験機によるテスト結果

\begin{tabular}{c|c|c|c|c|c}
\hline No. & ラテックス & $\begin{array}{c}\text { 塗料固形分濃度 } \\
(\%)\end{array}$ & $\begin{array}{c}\text { PET フィルム上の塗料の伸び } \mathrm{b} \\
(\mathrm{cm})\end{array}$ & $\begin{array}{c}\text { 上質紙上の塗料の伸び } \mathrm{a} \\
(\mathrm{cm})\end{array}$ & $\mathrm{a} / \mathrm{b}$ \\
\hline 1 & $\mathrm{~A}$ & 64.5 & 20.5 & 13.1 & 0.64 \\
2 & $\mathrm{~B}$ & 64.5 & 21.0 & 13.9 & 0.66 \\
2 & $\mathrm{~B}$ & 62.5 & 23.3 & 15.6 & 0.67 \\
3 & $\mathrm{C}$ & 64.5 & 20.8 & 14.6 & 0.70 \\
4 & $\mathrm{C}$ (CMC 0.5 部 $)$ & 62.5 & 19.5 & 12.1 & 0.62 \\
\hline
\end{tabular}


結果を表 9 に示す。PET フィルムは水の浸透は無 いと考えられ，その塗料の伸びは流動性を示している と考えられる。一方上質紙の場合は水を吸収しにくい ほど伸びは長く, 塗料の保水力と流動性に関係すると 考えられる。即ち表中の $\mathrm{a} / \mathrm{b}$ は塗料の保水力の指標 とみてよい。表 9 よりラテックス $\mathrm{C}$ が $\mathrm{a} / \mathrm{b}$ が大きい。 従って動的保水性が最も良いと考えられ, テストコー ターの結果とほぼ一致した。

\section{4. 結論}

（1）今回のテストコーターにおける塗工テストにお いて，ブリーディング発生に関してはハイシア 流動性と動的保水性に優れた塗料が良好な結果 となった。

（2）水分率計の使用により動的保水性をリアルタイ ムに測定することができ，ブリーディング発生 の指標となり得ることがわかった。

（3） IGT 試験器によるテストでも動的保水性の判
断ができると考えられる。

\section{謝 辞}

テストコーターでの塗工テストでは石川島播磨重工 怢)の皆様に多大なる御協力を頂きましたことを深く感 謝致します。

\section{参考文献}

1) O. T. Suontausta : 1993 Tappi Coating Conference Proceedings, 97.

2) R. E. Branston, K. Takamura, P. C. Clark, J. L. Vodnick, M. Errico, L. E. Scriven, J. G. Sheehan, and W. J. Suzynski : 1993 Tappi Coating Conference Proceedings, 79.

3) T. S. Young, D. E. Pivonka, L. G. Weyer, and B. Ching: 1993 Tappi Coating Conference Proceedings, 223.

4）浅山良行, 遠藤憲司：紙八゚研究発表会要旨集, 28 (1993). 